\title{
Physico-chemical limnology of a shallow lake in the floodplains of western Himalaya from last four decades: present status
}

\author{
Javaid Ahmad Shah ${ }^{1 *}$, Ashok K. Pandit ${ }^{1}$ and G. Mustafa Shah ${ }^{2}$
}

\begin{abstract}
Background: From the last few decades several lakes and wetlands showed water quality degradation that is one of the major problems globally resulting in serious environmental impacts and concern in both aquatic and terrestrial environs.

Methods: During this study we evaluated a number of water parameters [water temperature, depth, transparency, hydrogen ion concentration ( $\mathrm{pH}$ ), dissolved oxygen, chloride, calcium, magnesium, total alkalinity, nitrogen and phosphorus] on the monthly basis in September 2012-August 2013 in Hokersar wetland.

Results: From the year 1978 till 2012-13, the number of parameters showed an increasing trend except for $\mathrm{pH}$ and dissolved oxygen. Remarkable temporal variations were recorded in various parameters during the past and present study (e.g. dissolved oxygen showed a decrease of about $2.4 \mathrm{mg} / \mathrm{L}$ and pH 0.8 units. Calcium, magnesium, alkalinity, ammonical nitrogen and nitrate nitrogen depicted many fold increase in the last four decades). Among the recorded parameters significant positive correlations were observed between depth and chloride $(r=0.408, p<0.01)$; $p H$ and water temperature $(r=0.888, p<0.05)$; dissolved oxygen with total alkalinity $(r=0.790, p<0.05)$. However, negative correlation were maintained by water temperature with dissolved oxygen $(r=0.894, p<0.05)$, free carbon dioxide $(r=0.732, p<0.05)$ and calcium content $(r=0.868, p<0.05)$.

Conclusion: The study reflects that the wetland is under tremendous anthropogenic pressures from the immediate catchment. Further, from the study it is evident that total phosphorus raveled decreased levels as compared to previous years reflecting that the wetland still has spongy capacity for the major nutrient.
\end{abstract}

Keywords: Wetland, Dissolved oxygen, Nitrogen, Phosphorus, Anthropogenic pressure

\section{Introduction}

We often call wetlands as nature's kidney. Nature gave us with a variety of environments. Among those wetlands are the most beneficial to both aquatic as well human lives as they abate pollution by acting as sponges to major plant nutrients (Shah et al. 2015). Because of increase in population, urbanization and modernization wetlands are under the threat of extinction (Bhateria and Jain 2016). Human activities particularly in the catchment exploit the lakes, wetlands and their resources (Falah

\footnotetext{
*Correspondence: javaidshah31@gmail.com

${ }^{1}$ Centre of Research for Development (CORD), University of Kashmir,

Srinagar, J \& K 190006, India

Full list of author information is available at the end of the article
}

and Haghizadeh 2017). Threats to these aquatic ecosystems are diverse and include eutrophication or pollution caused by untreated domestic and agricultural effluents, besides these, siltation, deforestation of the watershed are the other reasons for the aforesaid systems particular to this Himalayan region. In Kashmir Himalaya Hokersar wetland also called as Queen wetland is also facing various problems like siltation, domestic sewage and agricultural runoff from the catchment areas. Besides, these the main problem with the wetland is that the immediate catchment is surrounded by agricultural land ( 2430 hectares) by which the wetland receives major waste in the form of agricultural effluents (4031 tonnes) that directly drain in this ecosystem annually (Khan 2010, 2015). 
Satellite imagery data indicate that open water is limited to $21.7 \%$ of the total wetland area, with the rest comprising marshland (35\%), cultivated land (15\%), plantation (12.5\%), submerged plants (10\%), and only (6\%) silted areas (Khan 2015). Keeping in view the drastic changes in the wetland, we made an attempt to pool the present data on water quality with the previously reported to have an insight regarding the present status of the Hokersar wetland.

\section{Materials and methods}

We determined various parameters of water on the monthly basis from September 2012-August 2013 following the standard methods given below.

The air temperature was recorded by using graduated mercury Celsius thermometer. The thermometer was placed in shade for at least $2 \mathrm{~min}$ for obtaining the air temperature. The results were expressed in ${ }^{\circ} \mathrm{C}$. The temperature of surface water was also obtained by using graduated mercury Celsius thermometer. The bulb of the thermometer was dipped in water for at least $2 \mathrm{~min}$ for obtaining the water temperature. The results were expressed in ${ }^{\circ} \mathrm{C}$.

Depth of all sampling sites was measured with the help of a weight tied to a string. This string along with weight was poured into the lake until the weight reached to the bottom and a mark was made on the string at this level. After lifting the string up, the depth was measured by a measuring tap graduated in meters, centimeters and millimeters. At shallow depths a graduated meter rod was used. The water transparency of the wetland was measured by a Secchi disc having a diameter of $20.0 \mathrm{~cm}$ and painted black and white alternately in a radial fashion. The disc was lowered in the water till it disappeared visually; being followed by its slow lifting till it reappeared. The depths of disappearance and reappearance of Secchi disc were noted and the average was taken as water transparency.

The hydrogen ion concentration $(\mathrm{pH})$ of all the study sites was carried by electronic pH meter (Model 335 systronics). Before measuring the hydrogen ion concentration, $\mathrm{pH}$ meter was calibrated against the standard buffer solution of $\mathrm{pH} 4.0$ and 9.2.

Dissolved oxygen of water sample was done on the spot by adding $1 \mathrm{~mL}$ of manganous sulfate $\left(\mathrm{MnSO}_{4}\right)$ and $1 \mathrm{~mL}$ of alkali-iodide-azide reagent. After precipitate formation, $1 \mathrm{~mL}$ of concentrated sulphuric acid $\left(\mathrm{H}_{2} \mathrm{SO}_{4}\right)$ was added for dissolution of precipitate. $50 \mathrm{~mL}$ of the sample was taken and titrated against $0.025 \mathrm{~N}$ sodium thiosulphate using starch as indicator.

For free carbon dioxide $\left(\mathrm{CO}_{2}\right) 50 \mathrm{~mL}$ of sample was taken in a flask, 2 drops of phenolphthalein indicator were added. If slight pink colour develops free $\mathrm{CO}_{2}$ was absent. If the solution remained colorless sample was tritrated with standard alkali titrant $(0.2 \mathrm{~N} \mathrm{NaOH})$ to reach the end point. Reading was noted and the free $\mathrm{CO}_{2}$ was calculated in milligram per litre.

For the determination of alkalinity $100 \mathrm{~mL}$ of water sample was titrated against $0.02 \mathrm{~N} \mathrm{H}_{2} \mathrm{SO}_{4}$, using 2-3 drops of phenolphthalein indicator. If no colour develops then add 2-3 drops methyl orange as an indicator. Total hardness of lake water was determined by taking $50 \mathrm{~mL}$ of well-mixed water sample, add $1-2 \mathrm{~mL}$ of buffer solution $\left(\mathrm{NH}_{4} \mathrm{Cl}-\mathrm{NH}_{4} \mathrm{OH}\right)$ and a pinch of EBT indicator and then titrated against $0.01 \mathrm{M}$ ethylene diamine tetra-acetic acid (EDTA) till wine red colour changes to blue (APHA 1998).

Calcium content of the sample was calculated by taking $25 \mathrm{~mL}$ of water sample, add $2 \mathrm{~mL}$ of $1 \mathrm{~N}$ sodium hydroxide $(\mathrm{NaOH})$ and a pinch of murexide indicator was added and then titrated against 0.01 N EDTA till purple colour appeared.

Magnesium content was obtained from the total hardness and calcium hardness by using the following formula:

$$
\begin{aligned}
& \text { Magnesium content }(\mathrm{mg} / \mathrm{L}) \\
& =(\text { Total hardness }- \text { Calcium content }) \times 0.243
\end{aligned}
$$

For the determination of chloride $100 \mathrm{~mL}$ sample was titrated against $0.0141 \mathrm{~N}$ of silver nitrate solution using potassium chromate as indicator till brick red colour end point was attained.

To $25 \mathrm{~mL}$ of water sample for the calculation of ammonical nitrogen, add $1 \mathrm{~mL}$ phenol, $1 \mathrm{~mL}$ sodium nitroprusside solution and $2.5 \mathrm{~mL}$ of oxidizing solution (10 mL Alkaline Citrate with $2.5 \mathrm{~g}$ of Sodium hypochlorite) and keep it at room temperature for about $1 \mathrm{~h}$ till the colour develops fully. The intensity of colour developed was measured at $640 \mathrm{~nm}$. Ammonium chloride was used for making various standards.

As far as nitrate nitrogen is concerned, $100 \mathrm{~mL}$ of water sample, $1 \mathrm{~mL}$ of sodium salicylate was added and evaporated to dryness on water bath. The residue was treated with $1 \mathrm{~mL}$ of concentrated sulphuric acid and after $5-10 \mathrm{~min} 6 \mathrm{~mL}$ of distilled water and $7 \mathrm{~mL}$ of $30 \%$ $\mathrm{NaOH}$ solution were added. After development of yellow colour, the intensity was measured at $410 \mathrm{~nm}$.

The orthophosphate phosphorus concentration was estimated by Stannous Chloride method. To $50 \mathrm{~mL}$ of water sample $4 \mathrm{~mL}$ of ammonium molybdate and $0.5 \mathrm{~mL}$ of stannous chloride was added. The intensity of blue colour developed was measured after $10 \mathrm{~min}$ at $690 \mathrm{~nm}$ spectrophotometrically (Systronics-116). Potassium dihydrogen phosphate was used for making various standards. 
The total phosphorus concentration was estimated by stannous chloride method. $50 \mathrm{~mL}$ sample was digested with $1 \mathrm{~mL}$ sulphuric acid and $5 \mathrm{~mL}$ nitric acid on hot plate to a volume of $1 \mathrm{~mL}$. The sample was then cooled and diluted with $20 \mathrm{~mL}$ distilled water. Then sample was titrated against $1 \mathrm{~N}$ sodium hydroxide solution with phenolphthalein as indicator, till faint pink colour appeared. Strong acid solution was used to discharge the colour. The final volume was again raised to $50 \mathrm{~mL}$ with distilled water. Then $4 \mathrm{~mL}$ molybdate reagent and 10 drops of stannous chloride were added to sample with continuous stirring. The intensity of blue colour developed was measured at $690 \mathrm{~nm}$ spectrophotomerically between 10 and $20 \mathrm{~min}$. The various standards were made from potassium dihydrogen phosphate and the results were expressed in $\mu \mathrm{g} / \mathrm{L}$ (Wetzel and Gliken 2000).

\section{Statistical analyses}

Statistical analyses were performed by various software's like SPSS (Version 22), PAST (Version 6.1) Biodiversity Pro and Origin (Version 6.0).

\section{Study area}

Jammu and Kashmir is the crown of Indian subcontinent and forms the northernmost part of India. The State of Jammu and Kashmir (J\&K) measures about $425 \mathrm{~km}$ from north to south and extends over $250 \mathrm{~km}$ from east to west. It is divided into three administrative divisions i.e., Jammu, Kashmir and Ladakh. As per the absolute location of $J \& \mathrm{~K}$ is concerned, it is located at a latitude of $32^{\circ} 017^{\prime \prime}-37^{\circ} 0.06^{\prime \prime} \mathrm{N}$ and a longitude of $37^{\circ} 26^{\prime \prime}-80^{\circ} 26^{\prime \prime} \mathrm{E}$. The valley of Kashmir is located in the middle of the Himalaya between $33^{\circ} 20^{\prime \prime}$ and $34^{\circ} 54^{\prime \prime} \mathrm{N}$ and $73^{\circ} 55^{\prime \prime}$ and $75^{\circ} 35^{\prime \prime} \mathrm{E}$ and covers an area of $15,948 \mathrm{~km}^{2}$. Kashmir which is referred to as the "Paradise on earth" is famous for its tall and towering mountains with snow capped peaks, the lush green margs (meadows), dense forests, undulating caraways, smooth and fertile valleys, gushing streams and zigzag rivers; freshwater lakes, cold and hot springs and the picturesque topography offers the most beautiful scenic spot in the world. The valley of Kashmir finds no match in the Himalaya while considering its water bodies, total run-off and the length of its watercourses. The valley has a great diversity of freshwater bodies including wetlands, lakes, streams and ponds and among these the first two assume great significance in embodying rich biodiversity. Almost all these water bodies play an important role in the socio-economic and ecology of the valley. Among the lakes and wetlands Hokersar $\left(34^{\circ} 05^{\prime} \mathrm{N}-34^{\circ} 06^{\prime} \mathrm{N}\right.$ latitude and $74^{\circ} 8-74^{\circ} 12^{\prime} \mathrm{E}$ longitude) assume greater significance as it is recognized as "Ramsar Site", Wetland of International importance. The wetland, situated at an altitude of $1584 \mathrm{~m}$ (amsl), was once spread over an area of $19.5 \mathrm{~km}^{2}$, and has presently got reduced to about $13.26 \mathrm{~km}^{2}$ at present Ahmad et al. (2014). The wetland is fed by two inlet streams, Doodhganga from east and Sukhnag Nalla from west. The excess water is drained out through an outlet gate known as NeedleGate on the north-west of the wetland near the village Sozieth, having a weir and lock system, which regulates the water level to provide a better habitat for migratory waterfowl during winter (Shah et al. 2015) (Fig. 1).

\section{Result and discussion}

Water is a requisite medium between varied factors that plays a decisive role in wetland ecology and the quality and management of water is a fundamental part for wetland conservation. Further, the importance of water for aquatic life as the fulcrum of biochemical metabolism rests on its physical and chemical properties (Shah et al. 2015; Bhateria and Jain 2016; Falah and Haghizadeh 2017).

\section{Air and water temperature}

One of the most outstanding and biologically significant phenomenon of aquatic bodies is the thermal regime. Further, majority of the biochemical processes, being temperature dependent, have very frequently been used as an important parameter. As is usual for temperate climates, the atmospheric temperature during the period of present investigation depicted a definite seasonal trend, with maximum values being recorded in summer and minimum in winter (Fig. 2). The water temperature corresponds to the air temperature, as is common for the shallow water bodies (Wetzel 1975). In all previous studies, the maximum water temperature was $29.2{ }^{\circ} \mathrm{C}$ as reported by Rather et al. (2001). However, present study depicts higher temperatures with $31.3{ }^{\circ} \mathrm{C}$ (Fig. 3). As far as maximum depth of the wetland is concerned

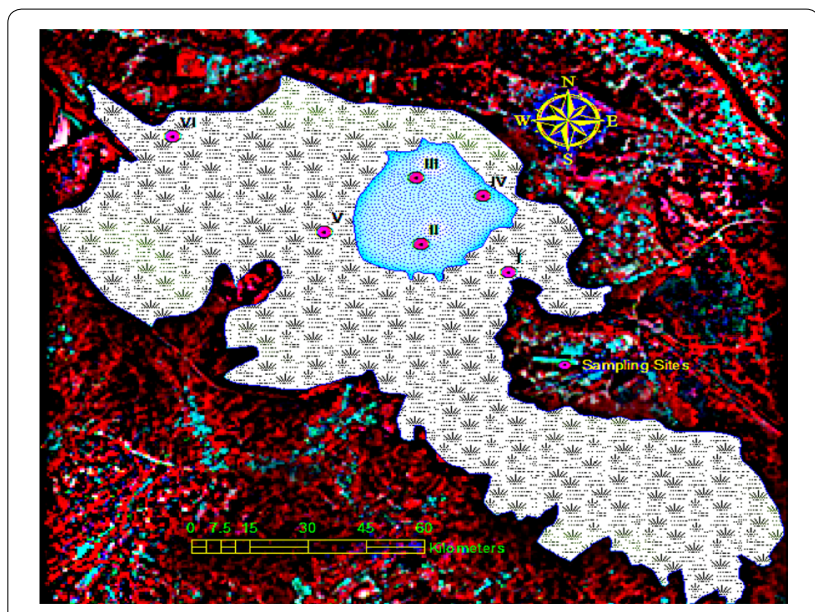

Fig. 1 Hokersar wetland with six sampling sites 

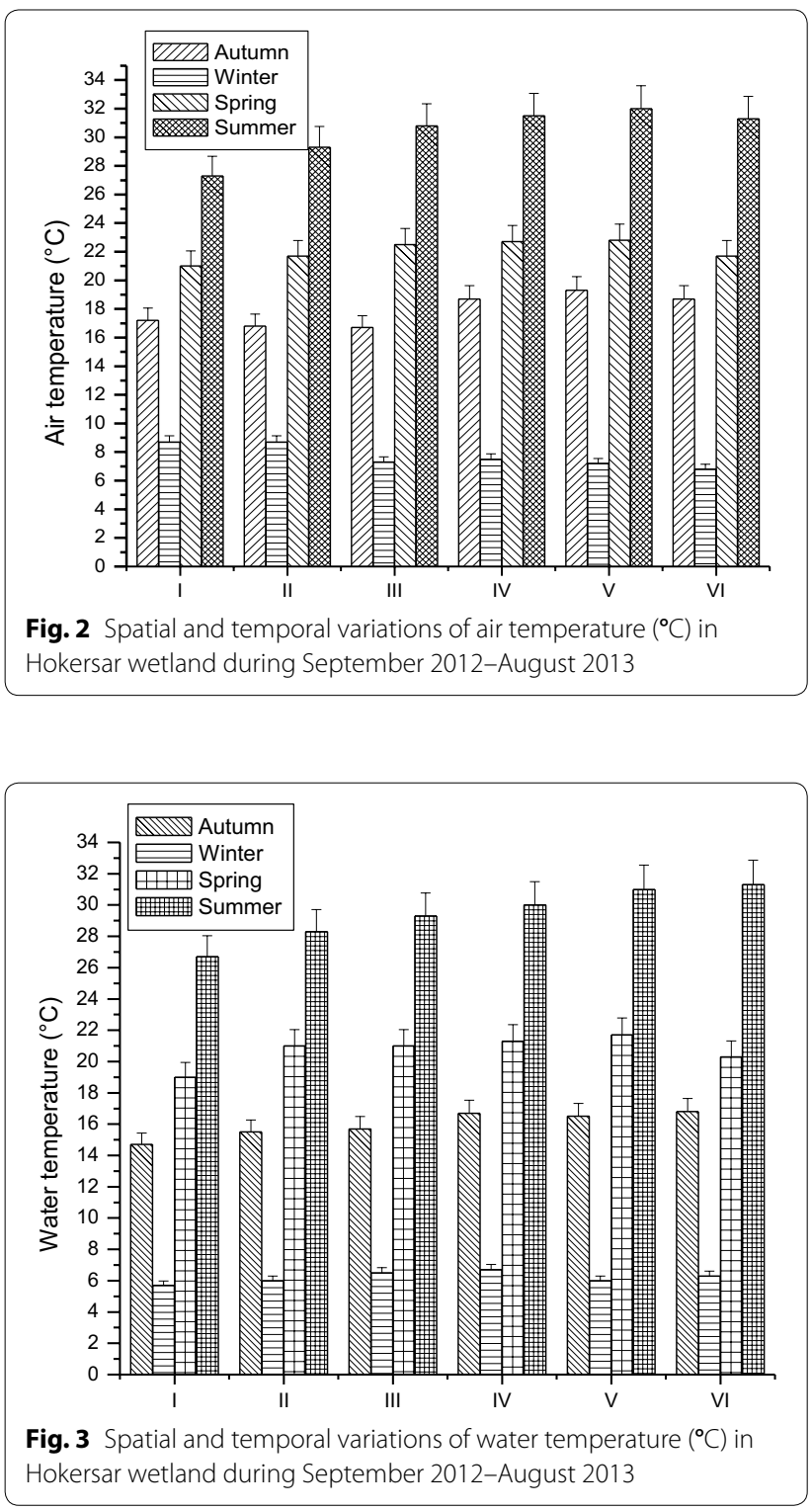

Pandit (1980) and Khan (2000) reported above $1 \mathrm{~m}$ depth (Table 1).

\section{Depth and transparency}

The depth of water in a water body is one of the major physical factors which act as a controlling factor for determining the water quality as well as the wealth of flora and fauna. The present study depicts higher depth ranges $0.4-2.7 \mathrm{~m}$ (Fig. 4) when compared with the previous workers like Pandit (1980), Khan (2000), Rather and Pandit (2002) etc. Higher depth values can be attributed directly to higher precipitation rate resulting in greater water discharge from the inlet in the wetland (Kumar and Pandit 2007) besides manual dredging activities can play an important role in higher depth ranges. In an aquatic ecosystem water transparency is one of the most important feature that control the energy relationship at different trophic levels. In this wetland, greater water transparency was recorded in autumn, followed by winter, summer and decreasing to the lowest during spring (Fig. 5). Higher transparency values during the autumn may be attributed to the fact that the wetland remains undisturbed by the concerned authorities and no dredging is allowed in this particular season. Further, clear water zones can be observed as least migratory birds visit this wetland in this particular season. Furthermore, high plankton population in spring and summer may result in low transparency besides, high influx from the streams that are feeding the wetland.

\section{The hydrogen ion concentration}

$\mathrm{pH}$ is the most important parameter in determining the corrosive nature of water. Higher the $\mathrm{pH}$ value lower is the corrosive nature of the same (Bhateria and Jain 2016). It is a major environmental factor of aquatic ecosystems at the interface of physicochemical and biological processes. It is regulated by carbonate equilibrium, in most inland waters, and is impacted by biological processes such as photosynthesis and respiration within the ecosystem (Weisse and Stadler 2006). The diminished rate of photosynthetic activity and the absorption of carbon dioxide and bicarbonates are eventually accountable for higher $\mathrm{pH}$ the lower oxygen values coincided with high temperature during summer (Fig. 6). The present $\mathrm{pH}$ values showed none significant variation in the wetland reflecting alkaline nature over the decades and is in close conformity with Khan (2000). The authors like Kaul et al. (1978), Handoo (1978), Rather et al. (2001) have reported much higher ranges as compared to present study.

\section{Dissolved oxygen}

Dissolved oxygen concentrations in natural water depend on the physical, chemical and biological activities in the waterbody. The source of oxygen in water is photosynthesis by phytoplankton and also oxygen dissolved from atmosphere. Higher values of dissolved oxygen values were reported only by Rather et al. (2001). The present study depicts lower values ranged between 2.4 and $10.1 \mathrm{mg} / \mathrm{L}$ (Fig. 7) reflecting that the wetland is moving towards more anoxic conditions in summer and is in close proximity with the previous findings of Pandit and Kumar (2006) in the wetland. Because of the higher trophic status, excessive growth of macrophytes occurs in the wetland which form mats over water surface blocking light penetration and, therefore, decreasing submerged growth due to cessation of underwater photosynthesis and thus creating anoxic conditions (Kaul et al. 1978). 
Table 1 Range of various physico-chemical parameters of Hokersar wetland from 1978 to 2012-2013

\begin{tabular}{|c|c|c|c|c|c|c|c|c|}
\hline Parameters & $\begin{array}{l}\text { Kaul et al. } \\
\text { (1978) }\end{array}$ & $\begin{array}{l}\text { Handoo } \\
(1978)\end{array}$ & $\begin{array}{l}\text { Pandit } \\
(1980)\end{array}$ & $\begin{array}{l}\text { Khan } \\
(2000)\end{array}$ & $\begin{array}{l}\text { Rather et al. } \\
(2001)\end{array}$ & $\begin{array}{l}\text { Rather } \\
\text { and Pandit } \\
(2002)\end{array}$ & $\begin{array}{l}\text { Pandit } \\
\text { and Kumar } \\
(2006)\end{array}$ & $\begin{array}{l}\text { Present study } \\
(2012-13)\end{array}$ \\
\hline Air temperature $\left(\mathrm{C}^{\circ}\right)$ & - & - & - & - & - & - & - & $6.8-31.5$ \\
\hline Water temp. $\left(C^{\circ}\right)$ & - & - & - & - & $4.6-29.2$ & $6.9-29.0$ & $3.0-27.0$ & $5.7-31.3$ \\
\hline Depth (m) & - & - & $0.66-1.12$ & $0.5-1.6$ & $0.13-1.6$ & $0.15-0.63$ & $0.54-0.63$ & $0.4-2.7$ \\
\hline Transparency (m) & - & - & & & $0.11-0.55$ & - & $0.54-1.22$ & 31.7-96.7 (\%) \\
\hline $\mathrm{pH}$ & $7.2-9.0$ & $7.2-9.0$ & $7.4-8.5$ & $7.2-8.5$ & $7.4-9.0$ & $7.5-8.6$ & $7.32-8.10$ & $7.1-8.2$ \\
\hline Dissolved oxygen (mg/L) & $3.20-12.50$ & $3.20-12.50$ & $4.0-8.02$ & $4.5-8.0$ & $2.6-15.20$ & $2.25-12.50$ & $1.9-11.4$ & $2.4-10.1$ \\
\hline Free carbon dioxide (mg/L) & - & - & - & - & - & - & - & $8-31.7$ \\
\hline Alkalinity (mg/L) & $85.0-256.0$ & $85-256.0$ & $98.0-268.0$ & - & $50.0-415.0$ & $68.02-352.0$ & $119.0-240.0$ & $91.3-254.7$ \\
\hline Total hardness (mg/L) & - & - & - & - & - & - & - & $69-214$ \\
\hline Calcium (mg/L) & $24.0-61.0$ & $23.60-61.60$ & $33.0-49.0$ & - & $26.45-54.30$ & $30.5-45.8$ & $27.3-39.6$ & $44.2-107.2$ \\
\hline Magnesium (mg/L) & $11.0-18.0$ & $2.50-7.40$ & $11.0-17.0$ & - & $7.05-16.74$ & $9.0-16.2$ & $2.4-8.2$ & $6.2-28.1$ \\
\hline Chloride (mg/L) & & & & - & $8.0-70.0$ & $10.0-32.0$ & $17.0-28.0$ & $10.3-39.3$ \\
\hline Orthophosphate ( $\mu \mathrm{g} / \mathrm{L})$ & $112.0-306$ & $112.0-306.0$ & $22.0-54.0$ & - & $40.0-255.0$ & $44.0-161.0$ & $33.0-141.0$ & $50.7-165$ \\
\hline Total phosphate ( $\mu \mathrm{g} / \mathrm{L})$ & $155.0-325$ & $155.0-306.0$ & $80.0-415.0$ & - & $115.0-535.0$ & $113.0-373.0$ & $116.0-307.0$ & $104.7-259.3$ \\
\hline Ammonical nitrogen $(\mu \mathrm{g} / \mathrm{L})$ & $3.0-10.0$ & $3.0-9.0$ & $16.0-69.0$ & - & $65.0-425.0$ & $83.0-395.0$ & $81.0-173.0$ & $16.7-242.3$ \\
\hline Nitrate nitrogen $(\mu \mathrm{g} / \mathrm{L})$ & 104.0-327.0 & $154-327.0$ & $73.0-621.0$ & - & $150-520.0$ & $186.0-420.0$ & $269.0-622.0$ & $226.3-631.3$ \\
\hline
\end{tabular}

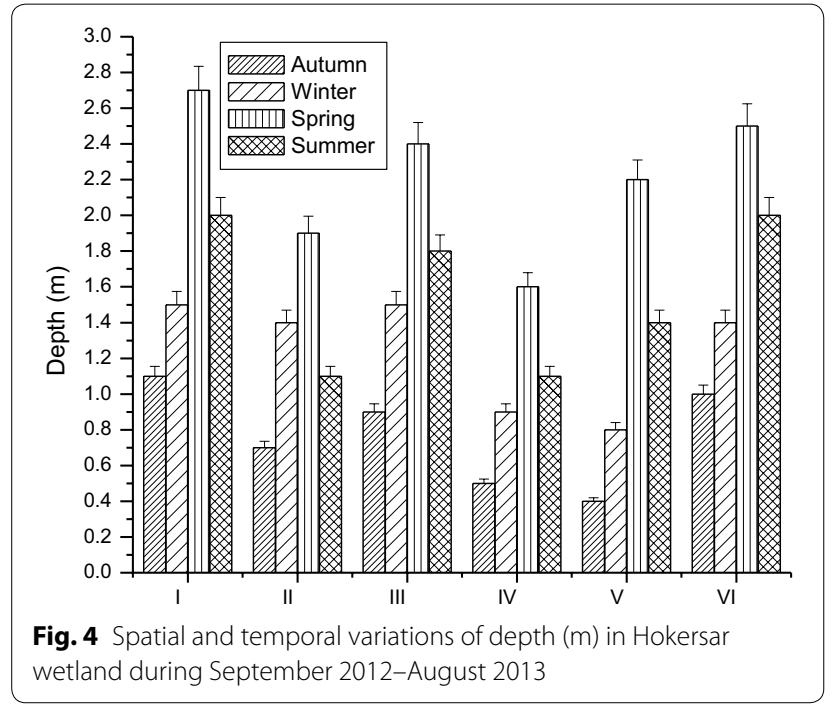

The first ever conducted survey published of Kaul et al. (1978) depicted the range of 7.2 to $9.0 \mathrm{mg} / \mathrm{L}$, which was supported by Handoo (1978). However, 2 years later Pandit (1980) observed decreased values of the same got support from Khan (2000) after two decades. Further, among the previous workers Rather et al. (2001) reported much higher values (15.20) as compared to other workers.

\section{Free carbon dioxide}

The importance of free carbon dioxide for autotrophic plants is very well known as they are the primary

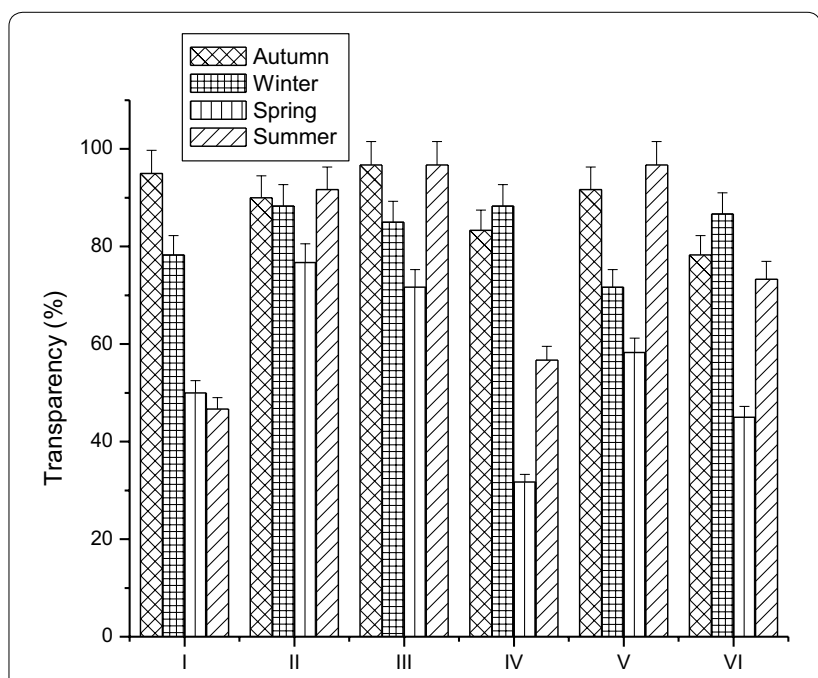

Fig. 5 Spatial and temporal variations of transparency (\%) in Hokersar wetland during September 2012-August 2013

producers on which the biotic components of aquatic ecosystem wholly depends. It is the basic raw material for the photosynthetic process. It alters the $\mathrm{pH}$ of water by forming carbonic acid, which further dissociates into carbonates and bicarbonates. Hence the estimation of free carbon dioxide in aquatic medium is of great importance. The present findings were the first ever study conducted for the estimation of free carbon dioxide for the wetland. In this wetland, during the study period, the maximum values were noticed in winter $(26.2 \mathrm{mg} / \mathrm{L})$, followed by 


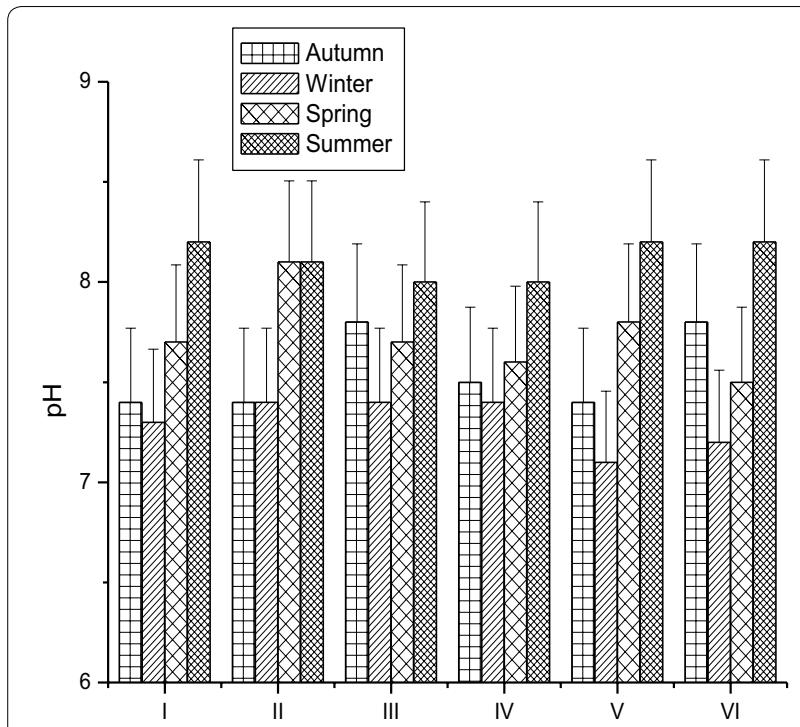

Fig. 6 Spatial and temporal variations $\mathrm{pH}$ in Hokersar wetland during September 2012-August 2013

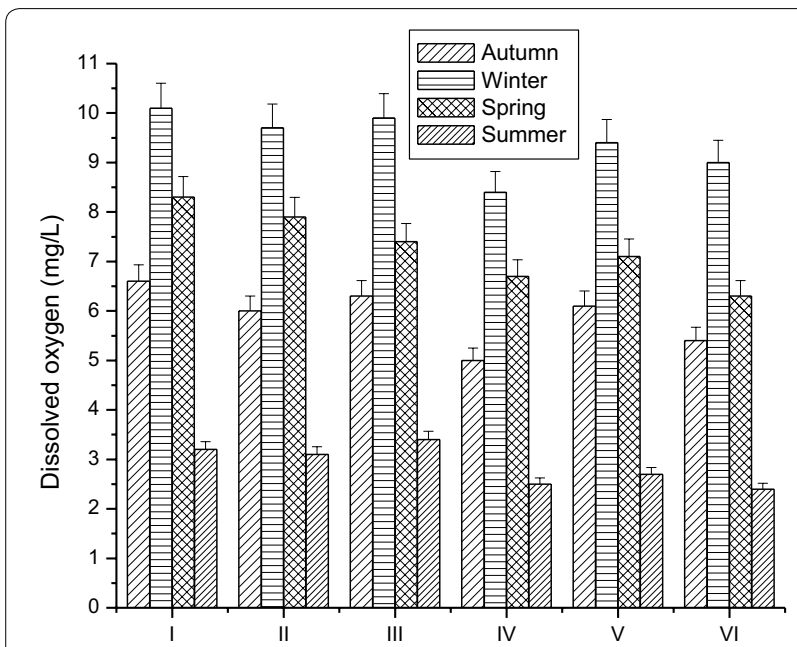

Fig. 7 Spatial and temporal variations of dissolved oxygen $(\mathrm{mg} / \mathrm{L})$ in Hokersar wetland during September 2012-August 2013

the spring $(20.2 \mathrm{mg} / \mathrm{L})$ and autumn $(18.7 \mathrm{mg} / \mathrm{L})$ till it reached its lowest $(9.9 \mathrm{mg} / \mathrm{L}$ ) in summer (Fig. 8). These observations are in line with the findings of Shah et al. (2015).

\section{Total alkalinity}

Alkalinity plays an important role in determining the ability of water to support algal growth and other aquatic life. The authors like Rather et al. (2001) predicted much higher values of total alkalinity and ranged between

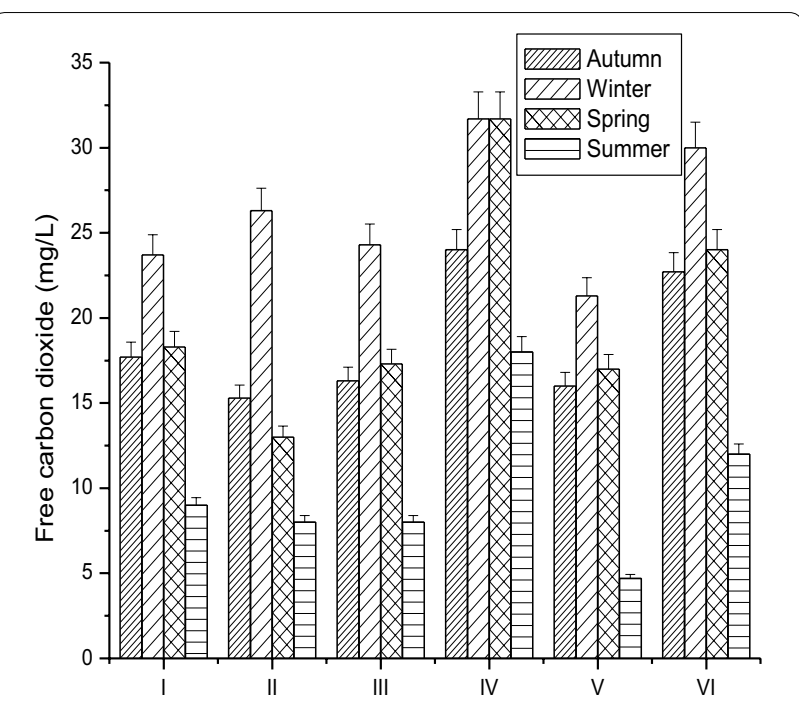

Fig. 8 Spatial and temporal variations of free carbon dioxide ( $\mathrm{mg} / \mathrm{L}$ ) in Hokersar wetland during September 2012-August 2013

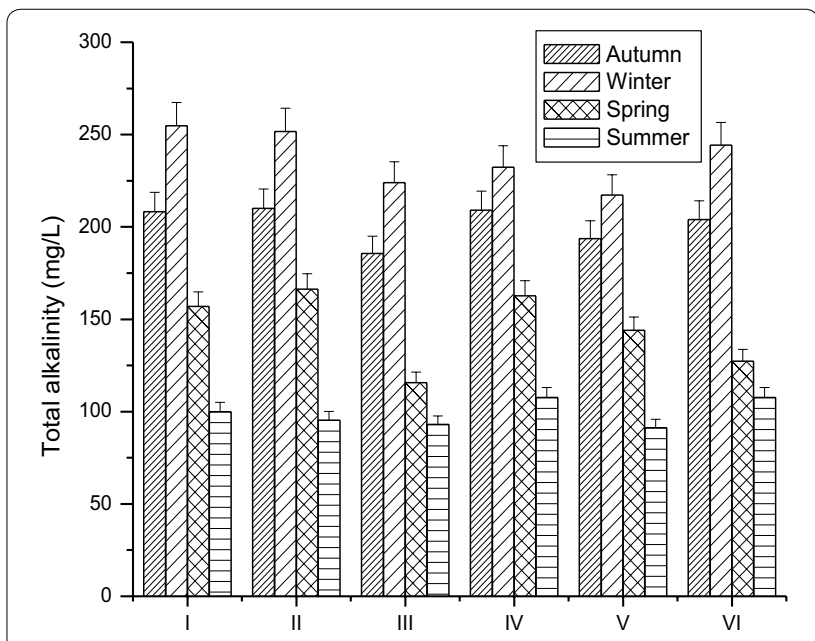

Fig. 9 Spatial and temporal variations of total alkalinity ( $\mathrm{mg} / \mathrm{L}$ ) in Hokersar wetland during September 2012-August 2013

(50.0-415.0 $\mathrm{mg} / \mathrm{L}$ ) as compared to our study (91.3$254.7 \mathrm{mg} / \mathrm{L}$ ). Further, higher values were observed in winter and lower values were noticed in summer (Fig. 9) in the present study, and are in line with the previous findings of Hassan et al. (2015) and Shah et al. (2014, 2015). Further, these results are in closer proximity with the findings of Kaul et al. (1978) and Handoo (1978). Among the previous workers like Rather et al. (2001) depicted much higher values $(415.0 \mathrm{mg} / \mathrm{L})$ of alkalinity which was not in collaboration with any of the findings in the last four decades. 


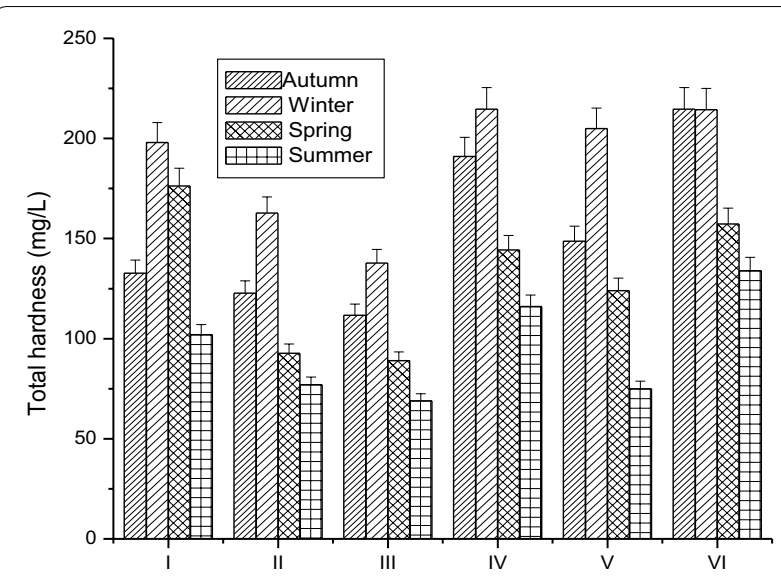

Fig. 10 Spatial and temporal variations of total hardness $(\mathrm{mg} / \mathrm{L})$ in Hokersar wetland during September 2012-August 2013

\section{Total hardness}

During the previous decades no data is available on the total hardness of the wetland. During the study period it was observed that higher values were evinced in winter registering $214.7 \mathrm{mg} / \mathrm{L}$ at site IV while lower values $(69.0 \mathrm{mg} / \mathrm{L})$ were registered in summer at site III (Fig. 10). This may be due to the high density of macrophytes and plankton in summer which use most of the salts for their growth and life processes, thereby increasing the $\mathrm{pH}$ of water and accelerating the de-calcification, resulting in decrease of hardness. Our results were in close conformity with Shah et al. $(2015,2017)$.

\section{Calcium and magnesium content}

The amounts of $\mathrm{Ca}^{2+}$ depicted summer fall in the wetland, a trend similar to that of alkalinity, due to uptake of $\mathrm{CO}_{2}$ by photosynthetic activity especially by submergeds and subsequent precipitation of calcium as calcium carbonate as a result of combination of elevated temperature in macrophytes beds and reduced $\mathrm{CaCO}_{3}$ solubility (Kaul et al. 1978; Pandit and Kumar 2006). The range of calcium content $(44.2-107.2 \mathrm{mg} / \mathrm{L})$ recorded in the present investigation is not in close agreement with any of the past findings (Fig. 11). Among the previous workers like Kaul et al. (1978), Handoo (1978), Pandit (1980) have observed nearly twofold low concentrations as compared to present study. Similarly, magnesium depicts higher values as compared to previous studies in the wetland (Fig. 12). Pandit and Kumar (2006) reported much lower concentration (2.4-8.2 mg/L) and were in close tune with Handoo (1978).

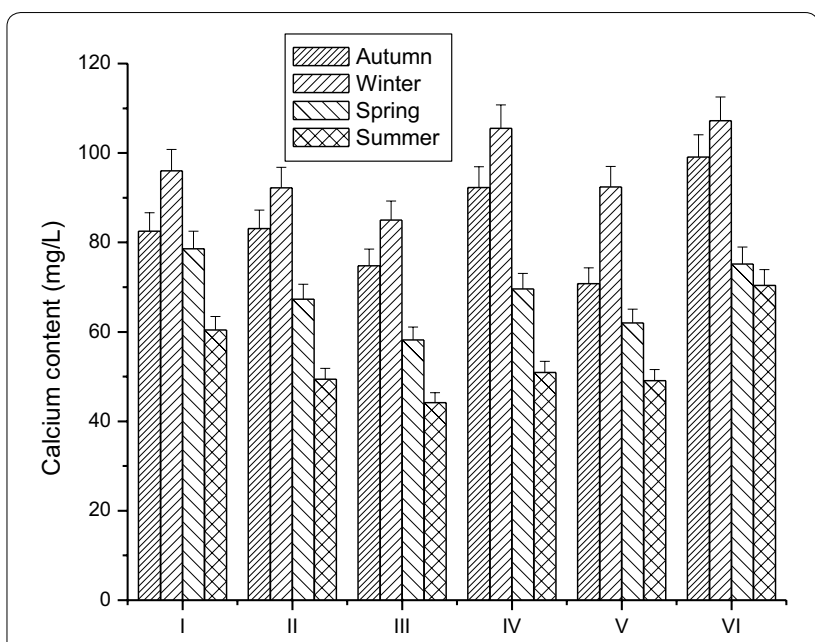

Fig. 11 Spatial and temporal variations of calcium content ( $\mathrm{mg} / \mathrm{L}$ ) in Hokersar wetland during September 2012-August 2013

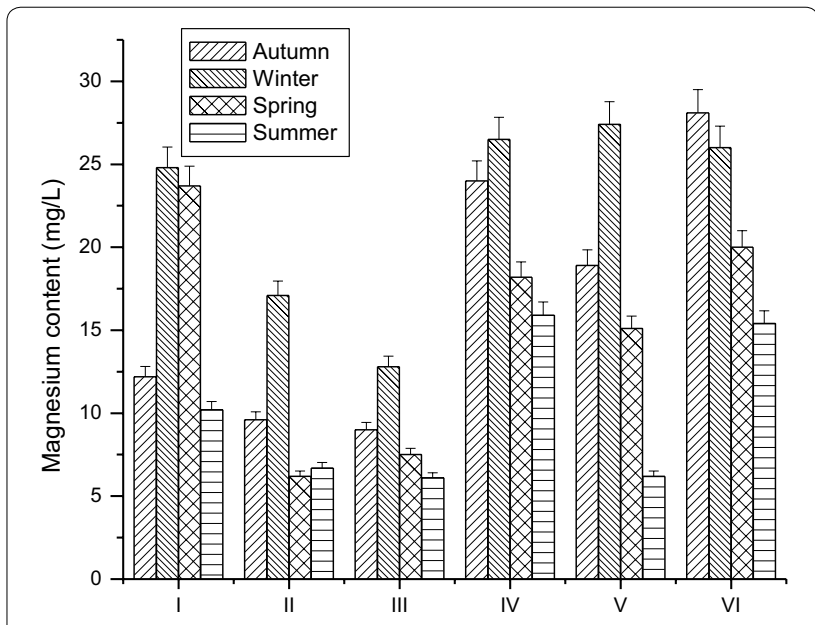

Fig. 12 Spatial and temporal variations of magnesium content (mg/L) in Hokersar wetland during September 2012-August 2013

\section{Chloride content}

The chloride content of the wetland was not done prior to Rather et al. (2001). Much higher values of chloride have been reported only by the former workers. The present work depicts 10 units increase in chloride concentration from last 10 years (Fig. 13). Pandit (1999) credited higher chloride content in warmer periods to both allochthonous and autochthonous substances organic in nature. 


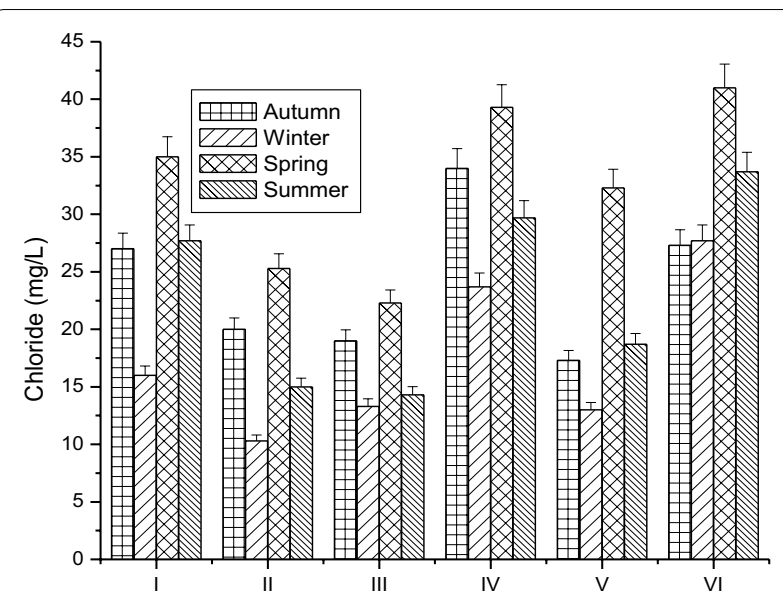

Fig. 13 Spatial and temporal variations of chloride $(\mathrm{mg} / \mathrm{L})$ in Hokersar wetland during September 2012-August 2013

\section{Phosphorus and nitrogen concentrations}

Earlier workers are of the view that Orthophosphate phosphorus concentration in the wetland is in very much high except Pandit (1980) who reported very low values $(22.0-54.0 \mu \mathrm{g} / \mathrm{L})$ as compared to the present study (Shah et al. 2015). However, the range of total phosphorus recorded in the present study is not in close agreement with any of the past findings (Shah et al. 2015). Low quantities of ammoniacal-nitrogen were reported by the Kaul et al. (1978) and Handoo (1978). We observed among the previously reported works of Rather and Pandit (2002) exceptionally very high values $(186-420 \mu \mathrm{g} / \mathrm{L})$ for the same parameter in the wetland.
The values of nitrate nitrogen are almost equal to that of Pandit (1980) and Pandit and Kumar (2006), while the authors have depicted a wider range. During the present investigation dissolved oxygen showed a negative correlation with air, water temperature and $\mathrm{pH}$. We observed positive correlation between calcium content and dissolved oxygen, free carbon dioxide and total alkalinity, calcium and magnesium contents (Table 2). Among the sites, sites II, III and V showed close similarity as they lie close to one another and having a good macrophytic growth during summer and autumn (Fig. 14). Site I showed greater dissimilarity with the remaining as it is located near the inlet of the wetland having high anthropogenic activity from the catchment.

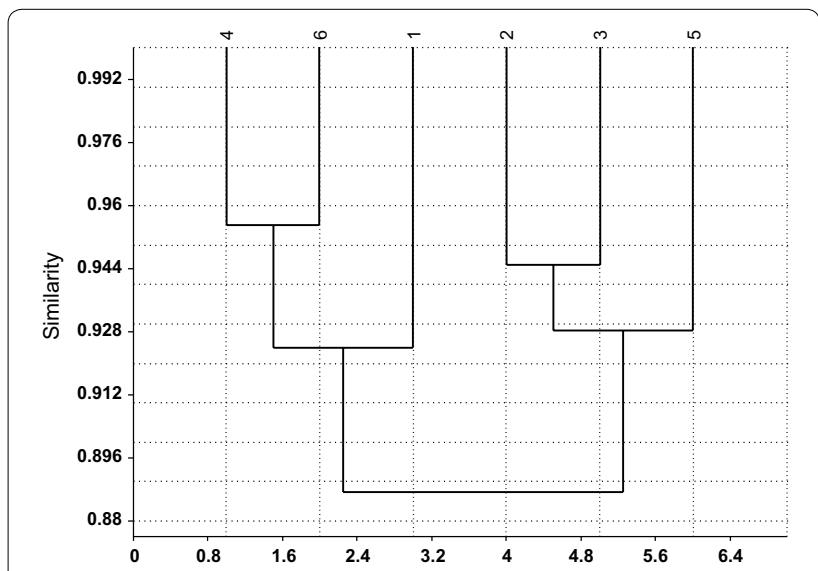

Fig. 14 Bray-Curtis Similarity index within sites

Table 2 Pearson correlation within various physico-chemical parameters of water in Hokersar wetland

\begin{tabular}{|c|c|c|c|c|c|c|c|c|c|c|c|}
\hline Parameters & 1 & 2 & 3 & 4 & 5 & 6 & 7 & 8 & 9 & 10 & 11 \\
\hline 1 & 1 & & & & & & & & & & \\
\hline 2 & $.996^{* *}$ & 1 & & & & & & & & & \\
\hline 3 & .308 & .321 & 1 & & & & & & & & \\
\hline 4 & -.224 & -.229 & $-.572^{* *}$ & 1 & & & & & & & \\
\hline 5 & $.871^{* *}$ & $.888^{* *}$ & .344 & -.117 & 1 & & & & & & \\
\hline 6 & $-.891^{* *}$ & $-.894^{* *}$ & .043 & .012 & $-.775^{* *}$ & 1 & & & & & \\
\hline 7 & $-.732^{* *}$ & $-.732^{* *}$ & -.140 & -.232 & $-.743^{* *}$ & $.674^{* *}$ & 1 & & & & \\
\hline 8 & $-.934^{* *}$ & $-.946^{* *}$ & $-.466^{*}$ & .296 & $-.836^{* *}$ & $.790^{* *}$ & $.720^{* *}$ & 1 & & & \\
\hline 9 & $-.721^{* *}$ & $-.726^{* *}$ & -.261 & -.093 & $-.709^{* *}$ & $.565^{* *}$ & $.791^{* *}$ & $.753^{* *}$ & 1 & & \\
\hline 10 & $-.872^{* *}$ & $-.868^{* *}$ & -.330 & .142 & $-.761^{* *}$ & $.683^{* *}$ & $.771^{* *}$ & $.904^{* *}$ & $.909 * *$ & 1 & \\
\hline 11 & $-.570^{* *}$ & $-.580^{* *}$ & -.197 & -.227 & $-.617^{* *}$ & $.448^{*}$ & $.736^{* *}$ & $.599^{* *}$ & $.969^{* *}$ & $.777^{* *}$ & 1 \\
\hline 12 & .319 & .328 & $.408^{*}$ & $-.702^{* *}$ & .165 & -.226 & .230 & -.261 & .167 & -.006 & .256 \\
\hline
\end{tabular}

${ }^{*}$ Correlation is significant at the 0.05 level (2-tailed)

${ }^{*}$ Correlation is significant at the 0.01 level

1 Air temperature, 2 water temperature, 3 Depth, 4 transparency, $5 \mathrm{pH}, 6$ dissolved oxygen, 7 free carbon dioxide 8 total alkalinity, 9 total hardness, 10 calcium content, 11 magnesium content, 12 chloride 


\section{Limitations of the study}

To manage the wetland we need to understand how they function, and how they interact with the surrounding landscape. We should have baseline information that can be used to inform the management of the wetland and need to understand why the wetland is under threat so as to address those threats.

\section{Conclusions}

From the last four decades the number of parameters showed an increasing trend except for $\mathrm{pH}$ and dissolved oxygen. Remarkable temporal variations were recorded in various parameters during the past and present study particularly for dissolved oxygen, nitrogen and phosphorus. These kinds of alterations would affect the aquatic environs as a decrease in dissolved oxygen, an increase in nitrogen and phosphorus contents would cause cultural eutrophication as reflected by the study. We recommend installation of sewage treatment plants near the inlet of the wetland so that purification methods should be adopted by filtration processes before introducing any loathsome material in the water body. Presently the wetland is under great threat due to untreated discharge of domestic sewage and agricultural effluents, washing clothes, animals are the contributing sources to the pollution of the wetland. Proper bioremediation techniques should be adopted to curtail the major pollutants released into the wetland from the immediate catchment so as to improve the water quality. It is further recommended that a real assessment of the water demand for human consumption and the minimum water based on the ecological requirements of floodplains should be undertaken at regular intervals to harness the benefits accrued through their natural function.

\section{Abbreviations \\ $\mathrm{pH}$ : hydrogen ion concentration; ${ }^{\circ} \mathrm{C}$ : degree centigrade; \%: percent; $\mathrm{mg} / \mathrm{L}$ : milligrams per liter; APHA: American Public Health Association; Km: kilometer; J\&K: Jammu and Kashmir; N: north; E: east; $\mathrm{km}^{2}$ : square kilometer; $\mathrm{m}$ : meter; amsl: above meter sea level; $\mu \mathrm{g} / \mathrm{L}$ : micrograms per liter.}

\section{Authors' contributions}

Research concept and design-JAS, AKP, GMS; Data analysis and interpretation-JAS; Writing the article-JAS; Critical revision of the article-JAS, AKP, GMS; Statistical analysis-JAS. All authors read and approved the final manuscript.

\section{Author details}

${ }^{1}$ Centre of Research for Development (CORD), University of Kashmir, Srinagar, J \& K 190006, India. ${ }^{2}$ Department of Zoology, University of Kashmir, Srinagar, J \& K 190006, India.

\section{Acknowledgements}

Thanks are due to the Director, Centre of Research for Development and Head, Environmental Science, University of Kashmir for providing necessary laboratory facilities.

\section{Competing interests}

The authors declare that they have no competing interests.

\section{Availability of data and materials}

No.

Consent for publication

Yes.

Ethics approval and consent to participate

The study requires no ethical approval.

Funding

No funding agency.

\section{Publisher's Note}

Springer Nature remains neutral with regard to jurisdictional claims in published maps and institutional affiliations.

Received: 10 December 2018 Accepted: 13 March 2019

Published online: 25 March 2019

\section{References}

Ahmad SS, Reshi ZA, Shah MA, Rashid I, Ara R, Andrabi SMA (2014) Phytoremediation potential of Phragmites australis in Hokersar Wetland-a Ramsar Site of Kashmir Himalaya. Int J Phytorem 16(12):1183-1191

American Public Health Association APHA (1998) Standard methods for the examination of water and waste waters. American Public Health Association, Washington DC

Bhateria R, Jain D (2016) Water quality assessment of lake water: a review. Sustain Water Resour Manag 2:161-173

Falah F, Haghizadeh A (2017) Hydrochemical evaluation of river water quality — a case study: Horroud River. Appl Water Sci 7:4725-4733

Handoo, JK (1978) Ecological and production studies of some typical wetlands of Kashmir. Ph.D. Thesis, University of Kashmir, Srinagar

Hassan Z, Shah JA, Kanth TA, Pandit AK (2015) Influence of and use/land cover on the water chemistry of Wular lake in Kashmir Himalaya (India). Ecol Process 4(9):1-11

Kaul V, Fotedar DN, Pandit AK, Trisal CL (1978) A comparative study of plankton populations in some typical fresh waterbodies of Jammu and Kashmir State. In: Sen DN, Bansal RP (eds) Environmental physiology and ecology of plants. B. Singh, M. P. Singh, Dehra Dun, pp 249-269

Khan MA (2000) Wetland biodiversity in the Kashmir Himalaya: assessment and conservation strategies. In: Khan MA (ed) Environmental biodiversity and conservation. APH. Publishing House, New Delhi, pp 69-93

Khan MA (2010) Environmental contamination of Hokersar wetland waters in Kashmir Himalayan valley, India. J Environ Sci Eng 52:157-162

Khan MA (2015) Environmental characteristics and phytoplankton productivity of a shallow Ramsar-site floodplain in the western Himalaya. Lakes Reserv 20:69-76

Kumar R, Pandit AK (2007) Physico-chemical characteristics of water in Hokerser wetland in Kashmir Himalaya. Pollut Res 26(4):73-79

Pandit AK (1980) Biotic Factor and Food Chain Structure in Some Typical Wetlands of Kashmir. Ph.D. Thesis, University of Kashmir, Srinagar-190006, J and K, India

Pandit AK (1999) Freshwater ecosystems of the Himalaya. Parthenon Publishing, New York, London

Pandit AK, Kumar R (2006) Comparative studies on ecology of Hokersar Wetland, Kashmir: present and past. J Himalayan Ecol Sustain Dev 1:73-81

Rather SA, Pandit AK (2002) Phytoplankton dynamics in Hokarsar wetland, Kashmir. J Res Dev 2:25-46

Rather SA, Bhat Shamim A, Pandit AK (2001) Water quality of Hokarsar, a typical wetland of Kashmir. J Res Dev 1:39-44

Shah JA, Pandit AK, Shah GM (2014) Spatial and temporal variations of nitrogen and phosphorus in wular lake leading to eutrophication. Ecologia 4(2):44-55 
Shah JA, Pandit AK, Shah GM (2015) Dynamics of key plant nutrients (N \& P) in Hokersar, a typical wetland of Kashmir Himalaya, India. J Environ Eng Ecol Sci 4(1):1-7

Shah JA, Pandit AK, Shah GM (2017) Dynamics of physico-chemical limnology of a shallow wetland in Kashmir Himalaya (India). Sustain Water Resour Manag 3(4):465-477
Weisse T, Stadler P (2006) Effect of pH on growth, cell volume, and production of freshwater ciliates, and implications for their distribution. Limnol Oceanogr 51(4):1708-1715

Wetzel RG (1975) Limnology. Saunders Company, Philadelphia, p 743

Wetzel RG, Gliken GE (2000) Limnological analyses, 3rd edn. Springer Science Business Media, New York, p 429

\section{Submit your manuscript to a SpringerOpen ${ }^{\circ}$ journal and benefit from:}

- Convenient online submission

- Rigorous peer review

- Open access: articles freely available online

- High visibility within the field

- Retaining the copyright to your article

Submit your next manuscript at $\boldsymbol{\nabla}$ springeropen.com 